\title{
Psychological career resources, career adaptability and work engagement of generational cohorts in the media industry
}

\begin{tabular}{|c|c|}
\hline \multicolumn{2}{|c|}{$\begin{array}{l}\text { Authors: } \\
\text { Melinde Coetzee }^{1} \text { (D) } \\
\text { Nadia Ferreira }^{2} \text { (D) } \\
\text { Crysanther Shunmugum }^{1}\end{array}$} \\
\hline \multicolumn{2}{|c|}{$\begin{array}{l}\text { Affiliations: } \\
{ }^{1} \text { Department of Industrial } \\
\text { and Organisational } \\
\text { Psychology, University of } \\
\text { South Africa, South Africa }\end{array}$} \\
\hline \multicolumn{2}{|c|}{$\begin{array}{l}{ }^{2} \text { Department of Human } \\
\text { Resource Management, } \\
\text { University of South Africa, } \\
\text { South Africa }\end{array}$} \\
\hline \multicolumn{2}{|c|}{$\begin{array}{l}\text { Corresponding author: } \\
\text { Nadia Ferreira, } \\
\text { ferren@unisa.ac.za }\end{array}$} \\
\hline \multicolumn{2}{|c|}{$\begin{array}{l}\text { Dates: } \\
\text { Received: } 27 \text { Sept. } 2016 \\
\text { Accepted: } 24 \text { July } 2017 \\
\text { Published: } 13 \text { Nov. } 2017\end{array}$} \\
\hline \multicolumn{2}{|c|}{$\begin{array}{l}\text { How to cite this article: } \\
\text { Coetzee, M., Ferreira, N., \& } \\
\text { Shunmugum, C. (2017). } \\
\text { Psychological career } \\
\text { resources, career adaptability } \\
\text { and work engagement of } \\
\text { generational cohorts in the } \\
\text { media industry. SA Journal of } \\
\text { Human Resource } \\
\text { Management/SA Tydskrif vir } \\
\text { Menslikehulpbronbestuur, } \\
\text { 15(0), a868. https://doi. } \\
\text { org/10.4102/sajhrm. } \\
\text { v15i0.868 }\end{array}$} \\
\hline \multicolumn{2}{|c|}{$\begin{array}{l}\text { Copyright: } \\
\text { (C) 2017. The Authors. } \\
\text { Licensee: AOSIS. This } \\
\text { is licensed under the } \\
\text { Creative Commons } \\
\text { Attribution License. }\end{array}$} \\
\hline \multicolumn{2}{|l|}{ Read online: } \\
\hline 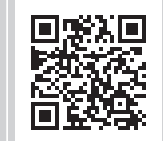 & $\begin{array}{l}\text { Scan this QR } \\
\text { code with your } \\
\text { smart phone or } \\
\text { mobile device } \\
\text { to read online. }\end{array}$ \\
\hline
\end{tabular}

Orientation: The global skills crisis coupled with the aging workforce, rapid technological advances and changing nature of work have infringed various challenges upon organisations and employees. Media organisations in particular are affected by these trends, with retention further at risk because of the specialised and scarce skills sought and the versatility and ambiguity inherent in the nature of careers within the media industry, therefore resulting in engagement and skills retention being high on the agenda.

Research purpose: The aim of the study was to explore whether employees' age, psychological career resources and career adaptability significantly predict their work engagement and whether generational cohorts differ significantly regarding these variables.

Motivation for the study: Within a retention context, it is important to gain insight into the employees' personal career-related capabilities and dispositions as these are deemed important for driving career development and engagement levels, which, in turn, impact on the retention of talent.

Research design, approach and method: A stratified random sample $(N=248)$ of predominantly female $(63.3 \%)$ and black African people $(54 \%)$ within their early career stages $(80 \%<45$ years) was used. A cross-sectional, quantitative research design approach was followed. Stepwise regression analyses and tests for significant mean differences were performed.

Main findings: The results indicated generational cohort (age), career confidence (career adaptability) and career harmonisers (psychological career resources) as significant predictors of work engagement. The Generation Y individuals had higher levels of psychological career resources (career preferences, career values and career drivers), while the Generation $X$ individuals had higher career curiosity. The Baby Boomers showed higher levels of work engagement.

Practical and managerial implications: Psycho-social career meta-capacities positively related to work engagement. It is therefore essential that these constructs are taken into account in career development and engagement practices, which, in turn, may contribute towards enhancing talent retention and employability of individuals within the media sector.

Contribution: The study contributed new insights on psychological factors among generational cohorts in the media industry that predict their work engagement and possible retention.

\section{Introduction}

\section{Key focus of the study}

Employees within the contemporary, ever changing world of work are faced with numerous challenges, such as diminished employment opportunities, uncertain career paths, reduced job security, fast-changing technology and an increasing personal responsibility for frequently re-evaluating and making adjustments to their careers (Chabault, Hulin \& Soparnot, 2012; Potgieter, 2012). In light of this context, organisations are required to prioritise their strategic mandate in attracting, retaining, engaging and developing key employees in order to increase their business performance and remain relevant (Del Corso \& Rehfuss, 2011; Obschonka, Silbereisen \& Wasilewski, 2012; Savickas, 2012; Savickas \& Porfeli, 2012; Schuler, Jackson \& Tarique, 2011).

Note: This article is partially based on the author's thesis of the degree of Doctor of Commerce in Industrial and Organisational Psychology at the University of South Africa, South Africa, with supervisor Prof. Melinde Coetzee, received June 2012, available here: http://uir.unisa. ac.za/bitstream/handle/10500/6722/thesis_ferreira_n.pdf?isAllowed=y\&sequence=1 
Individuals can no longer rely on organisational support mechanisms for their career success, but instead should rely on their personal and career-related capabilities and subjective career experiences (Coetzee, 2014). Both psychological career resources and career adaptability are argued to be functioning as drivers for employees' work engagement as a precursor for their performance and retention; that is, their intention to leave or stay within the organisation (Coetzee, 2014; Coetzer \& Rothmann, 2007; Mendes \& Stander, 2011; Tladinyane, 2013). The talent retention agenda is intensified with factors such as different generations working side by side within today's organisations, each bringing unique talents and skills to further the business competiveness of the organisation (Cates, 2010; Kupperschmidt, 2000; Venus, 2011).

Generational cohorts are perceived as possessing their own set of motivators, values and preferences, all of which may uniquely influence their subjective or internal work experiences, such as their adaptability and career resources, engagement and intention to stay or leave the organisation (Festing \& Schaefer, 2014; Lyons, Duzbury \& Higgins, 2006; Nkomo, 2013; Tansley, 2011; Thunnissen, Boselie \& Fruytier, 2013). Therefore, the focus is on psychological career resources and career adaptability in relation to work engagement across the different generational cohorts. Developing consciousness of individuals' subjective career experiences, that is, their psychological career resources, career adaptability and work engagement, should assist organisations with designing customised interventions in alignment with their workforces' career needs, preferences, motivations and career aspirations, which, in turn, may assist with employee retention and development (Shunmugum, 2016).

\section{Background to the study}

Restructuring, the re-organisation of production processes, the need to ensure economic viability and the use of increasingly advanced technology have led to drastic changes in the nature of careers and employment relationships in the media industry (International Labour Office, 2014). This has resulted in the workforce increasingly facing instability and ambiguity throughout their careers, as they are no longer guaranteed job security, loyalty and linear career paths by their employers (Lent, 2013; Santilli, Nota, Ginevra \& Soresi, 2014; Segers \& Inceoglu, 2012; Zacher, 2014). These experiences may have an adverse impact on individuals' energy, dedication and interest to the organisation, that is, impacting the extent to which employees are engaged. Furthermore, this might influence the retention of valuable talent within organisations (Festing \& Schafer, 2014; Mohlala, Goldman \& Goosen, 2012; Olckers \& Du Plessis, 2012).

Media organisations often depend on talent, human creativity and a highly specialised and skilled workforce in order to drive their core strategic mandate (International Labour Office, 2014). Therefore, employees in the media industry are required to be increasingly flexible, adaptable and continuously updated on their skills and knowledge. The main challenge pertaining to the participating organisation is the lack of organisational development knowledge and practices pertaining to career development and engagement strategies, which once embedded may positively contribute towards the career success, employability and retention of an organisation's high-potential employees (Festing \& Schafer, 2014; Mohlala et al., 2012).

Individuals' psycho-social career meta-capacities include a variety of self-regulatory adaptive capacities (Savickas \& Porfeli, 2012) such as career adaptability and active consciousness of one's career preferences, values, motivations, problem solving and relational skills, career self-management competencies, self-esteem and emotional literacy (Coetzee, 2014). These capacities enable individuals to become selfsufficient, adaptive learners in managing their own careers (Bezuidenhout, 2011; Coetzee \& Roythorne-Jacobs, 2012; Savickas \& Porfeli, 2012). Researchers emphasise that psychosocial career meta-capacities may affect the general employability attributes of an individual, which is viewed as an alternative to job security and thus a crucial enabler for career success in the 21st century workplace (Guest, Isaksson \& De Witte, 2010; Naute, Van Vianen, Van Der Heijden, Van Dam \& Willemsen, 2009; Savickas \& Porfeli, 2012). Therefore, more researchers and practitioners are arguing that organisations need to prioritise and integrate employees' career meta-capacities into their strategic talent retention strategies and interventions as it is believed to facilitate positive outcomes such as high level of work engagement, high-performance organisational culture, lifelong learning skills, career competencies, coping strategies and talent retention (Coetzee \& Roythorne-Jacobs, 2012; Coetzer \& Rothmann, 2007; Mendes \& Stander, 2011).

Additionally, it is noted that diversity is an important development and challenge within South African media organisations. Employers in South African organisations should seek to understand how individuals' sociodemographic characteristics, such as generational cohort (age), may influence their psycho-social career meta-capacities (psychological career resources and career adaptability) and their work engagement (Potgieter, 2012). The current work context requires individuals to realise and rely on their psycho-social resources or meta-capacities in order to manage and own their careers, achieve a sense of integration with their self and the environment, adapt to job demands and unplanned events and strive for personal and professional development (Coetzee, 2014; Ebberwein, Krieskok, Ulven \& Prosser, 2004; Hobfoll, Johnson, Ennis \& Jackson, 2003; Rottinghaus, Buelow, Matyja \& Schneider, 2012; Savickas \& Porfeli, 2012).

\section{Trends from the literature}

\section{Psychological career resources}

The concept of psychological career resources was developed by Coetzee $(2008,2014)$ and refers to all competencies and subjective experiences that significantly influence the promotion and facilitation of individuals' proactive career behaviour and career development over time. Other researchers state that psychological career 
resources include attributes and abilities such as behavioural adaptability, career orientation consciousness, self-insight, sense of purpose, self-esteem and emotional literacy (Coetzee, 2008; Ferreira, 2012; Ferreira, Basson \& Coetzee, 2010; Hall \& Chandler, 2005).

Coetzee's (2014) psychological career resources model is of specific relevance to this study, as it has been developed and tested for adults in the South African context (Bezuidenhout, 2011). The psychological career resource model encapsulates an integrated career framework, in order to provide a holistic picture of an individual's career enablers, career drivers, career harmonisers, career preferences and career values, which can be linked to an individual's extrinsic or intrinsic lifetime career experience that leads to career success (Gunz \& Heslin, 2005):

- Career preferences and values represent an ongoing cognitive roadmap of the career pathways that an individual perceives as interesting and meaningful to them (Coetzee, 2008, 2014). However, although career preferences and career values are intertwined, they are distinct from each other. Career preferences refer to the career actions or activities that guide long-term career growth and direction, while career values represent cognitive expressions of the ideas, needs or philosophies that are deemed as significant by the individual (Coetzee, 2014; Coetzee \& Esterhuizhen, 2010; Lyons et al., 2006). Therefore, an individual's preference can be influenced by his or her values and is therefore necessary to understand the concept of value in order to better understand the concept of preference. According to Coetzee's (2014) psychological career resources model, the four career preferences comprise of stability or expertise, managerial, creativity or variety and autonomy or independence and two overarching values, which include growth or development and authority or influence (Coetzee, 2008, 2014).

- Career enablers are seen as individuals' portable skills and abilities that can be conveyed across a variety of situations in order to help them achieve career success (Coetzee, 2008, 2014). Career enablers include an individual's practical or creative skills and self or other skills. Practical or creative skills are necessary for executing career options in original and inventive ways (e.g. conceptual thinking and problem-solving skills, goal setting, management skills and skills related to innovation and change, etc.), while self or other skills, often linked to one's emotional intelligence, are the skills necessary for self-reflection and effective interaction with others (e.g. self-awareness, empathy, self-management) (Coetzee, 2014; Ferreira et al., 2010).

- Career drivers compose of an individual's career purpose, career directedness and career venturing. Career drivers are considered to be the motivational enablers that stimulate experimentation, exploration and risk-taking behaviour with possible careers, based on a selfassessment of one's abilities for present and future work roles (Coetzee, 2008, 2014). These drivers, in return, provide a view of the possible self and roles that an individual can define, create or express within the career construction or design process.

- Career harmonisers are the psychological attributes that not only act as promoters of flexibility and resilience, but also as controls (because they keep career drivers in balance so that people do not burn themselves out in the process of pursuing and reinventing their careers) (Coetzee, 2008, 2014). Coetzee $(2008,2014)$ labels these career harmonisers attributes as self-esteem, behavioural adaptability, emotional literacy and social connectivity.

Individuals with a well-developed psychological career resources profile are also more likely to be engaged in their work and committed to their job, work, career, occupation or the organisation (Converse, Pathak, DePaul-Haddock, Gotlib \& Merbedone, 2012; Fugate, Kinicki \& Ashforth, 2004; Savickas \& Porfeli, 2012). A study by Tladinyane (2013) showed that individuals who reported high levels of selfesteem also exhibited high vigour and absorption to their work. Coetzee and Bergh (2009) reported that individuals' psychological career resources and sociodemographic variables predict their life satisfaction, job and career satisfaction, sense of happiness and the meaning they attach to the importance of work in their lives. Ferreira et al. (2010) indicated that the younger age group (25 and younger) reported higher on self-esteem and ability to form meaningful social relationships than older individuals (56 and older) age group. Their study further highlighted that individuals in the late career life stage (56 and older) appear to have a significantly higher need to venture out in search of new career opportunities (Ferreira \& Coetzee, 2010).

Psychological career resources underpin the key concepts at the core of the new economy career arrangement as they equip individuals with capacities to actively seek opportunities, update transferrable competencies and skills and transform into agentic and continuous learners (Coetzee, 2014; Potgieter, 2012). Therefore, the use of psychological career resources is likely to promote proactive career behaviour and empower the individual in controlling his or her employment journey and being relevant within a highly competitive environment, all of which will ultimately lead to higher levels of personal fulfilment and satisfaction.

\section{Career adaptability}

Career adaptability is a psycho-social construct that indicates an individual's readiness and resources for coping with current and anticipated occupational development tasks, vocational transitions as well as personal dramas (Ferreira, 2012; Guan et al., 2014; Ismail, Ferreira \& Coetzee, 2016; Öncel, 2014; Savickas, 2012). Various scholars have characterised career adaptability as a set of transactional resources (i.e. attitudes, competencies and behaviours) that facilitate employment seeking options and career improvement behaviour, assist with person - environment congruence and empower positive immersion into one's work (Klehe, Zikic, Van Vianen, Koen \& Buyken, 2012; 
Savickas, 1997, 2012; Tolentino, Garcia, Restubog, Bordia \& Tang, 2013). Career adaptability is underpinned by selfregulatory and agentic processes which are viewed as preparing individuals to plan and cope with current and anticipated occupational changes and transitions (Savickas \& Porfeli, 2012; Tolentino et al., 2013).

Savickas and Porfeli (2012) explain career adaptability as a multidimensional, hierarchical structure which comprises four subscales, namely, career concern, control, curiosity and confidence:

- Concern refers to an interest with aligning oneself to one's future goals, and acknowledgement that present actions (i.e. awareness, involvement and preparedness) are linked to attainment of future career aspirations.

- Control indicates self-discipline and taking responsibility for one's career through deliberate and conscientious decision-making, willpower and action.

- Curiosity is characterised by demonstrating openness to new experiences and possibilities, self and environmental exploration, inquiry and successive identification of career opportunities.

- Confidence is reflected in one's efficacious capacity to solve problems and navigate through challenges and obstacles in constructing their future.

Individuals draw from these four self-regulatory resources in order to craft solutions for adapting within a context of complexity and unfamiliarity pertaining to career development transitions, unplanned events and obstacles (Johnston, Luciano, Maggiori, Ruch \& Rossier, 2013; Maggiori, Johnston, Krings, Massoudi \& Rossier, 2013; Savickas \& Porfeli, 2012; Tolentino et al., 2013; Zacher, 2014).

Although studies tend to suggest no differences between age groups on career adaptability levels (Rossier, Zecca, Stauffer, Maggiori \& Dauwalder, 2012; Shunmugum, 2016), career adaptability is seen as an important set of psycho-social career meta-capacities that shape the problem-solving strategies and coping behaviours that individuals' use to synthesise their vocational self-concepts with work roles. Furthermore, as an important set of individual resources, career adaptability resources influence several other career-related variables and outcomes to various extents, such as work engagement, job satisfaction, career anxiety, successful job transitions, workstress and tenure (Brown, Bimrose, Barnes \& Hughes, 2012; Ismail et al., 2016; Rossier et al., 2012).

\section{Work engagement}

Work engagement includes experiencing a deeper dimension of well-being, emotional and behavioural responses, such as joy, energy and fulfilment at work (Hallberg \& Schaufeli, 2006; Maslach, Schaufeli \& Leiter, 2001; Schaufeli, 2013; Schaufeli, Bakker \& Van Rhenen, 2009). Schaufeli et al. (2009) define work engagement as a positive, fulfilling, workrelated state of mind that comprises three dimensions, namely, vigour, dedication and absorption:
- When employees are engaged, they exude high-energy levels and want to devote time and effort to their work (vigour).

- They feel enthusiastic, inspired and view their work tasks as a significant and meaningful pursuit (dedication).

- They are fully concentrated, giving sufficient attention to their work to the point whereby they experience time moving quickly (absorption).

Engaged employees harness themselves to their work by fully investing their heads, hearts and hands in performing their role (Breevaart, Bakker, Demerouti \& Hetland, 2012; Kahn \& Heaphy, 2014; Schaufeli, Bakker \& Salanova, 2006). Individuals' will become more or less interested (i.e. engaged) in activities as a function of the degree to which they experience and need satisfaction while engaging in those activities (Linley, Nielsen, Gillett \& Biswas-Diener, 2010). According to Saks (2006), work engagement is associated with an individual's attitudes, intentions and behaviours. Hence, engaged employees are likely to be more attached to their organisation and would have a lower propensity to leave the organisation (Schaufeli \& Bakker, 2004). This view is supported by several researchers who found that work engagement is negatively related to turnover intention (Bakker \& Demerouti, 2008).

Given the significance of work engagement for both the individual and the organisation, various researchers have explored the influence of certain biographical variables on the process of work engagement (Bezuidenhout, 2011; Schaufeli \& Bakker, 2004). Within South Africa's multicultural context, it may be beneficial to also explore the sociodemographic differences in relation to work engagement, as this information may assist organisations in customising their career development practices to suit the needs of each unique group. More specifically, older employees seem to be more engaged in their work (Schaufeli et al., 2006). Macey and Schneider (2008) indicated that full-time employees are more engaged than part-time employees because full-time individuals experience higher empowerment in terms of decision-making affecting their job or work and thus have high levels of engagement. Work engagement is related to a range of positive organisational outcomes such as job satisfaction, motivation, a decline in intention to quit, employee well-being and health (Rothmann \& Rothman, 2010; Schaufeli \& Bakker, 2004).

In conclusion, work engagement could be understood as the underlying energy of the organisation which might be utilised towards organisational success and individual benefits (Schaufeli et al., 2006). As personal resources are believed to contribute towards the employees' work engagement, attention needs to be given to the potential influence of psycho-social career meta-capacities (as explained by psychological career resources and career adaptability) on work engagement. In recent years, organisations have leaned on financial rewards and other benefits to uplift engagement levels (Schaufeli et al., 2009). However, the emerging trend that has come to the forefront is the notion that personal 
resources, or psycho-social career meta-capacities (rather than taking the approach solely on external rewards and factors) could be employed as the driver of engagement (Hoole \& Bonnema, 2015)

\section{Generational cohorts}

Researchers have long argued whether differences exist among generational cohorts in terms of what motivates and drives them to perform optimally (Drake, 2012; Ismail et al., 2016; Kapoor \& Solomon, 2011). Recent years have seen trends in older employees' working past their expected retirement age (Boone-James, Mckechnie \& Swanberg, 2011; Miller \& Nyce, 2014), thereby disregarding premature beliefs that older workers are less engaged. If differences between generational cohorts exist, engagement strategies need to be adjusted and customised accordingly. This study will therefore seek to increase the understanding on the interaction of these variables by testing whether there are significant differences between the levels of engagement and the psychosocial career meta-capacities (psychological career resources and career adaptability) among different generational (age) cohorts. The generational cohorts of relevance to the study included Generation Y (18-40 years), Generation X (40-49 years) and Baby Boomers (50+ years).

There seems to be a paucity of research in the South African context on the association between individuals' psychosocial career meta-capacities (psychological career resources and career adaptability) and work engagement and how individuals from different generational cohorts (age) differ regarding these variables, especially in South Africa's multicultural organisational context.

This study contributes to the discipline of career psychology by exploring if individuals' generational cohort (age) and their psycho-social career metal-capacities significantly and positively predict their work engagement. Furthermore, research in the generational cohort realm is also limited in the South African work context. Therefore, this study aims to address this gap by exploring individuals' psychological career resources and career adaptability in relation to other internal career resources such as work engagement and how these manifest in the three generational cohorts: Generation Y (18-40 years), Generation X (40-49 years) and Baby Boomers (50+ years).

\section{Research objective}

The present study aimed to investigated (1) whether individuals psycho-social career meta-capacities predict their work engagement and (2) the differences between generational cohort (age) in terms of their career metacapacities (psychological career resources and career adaptability) and employee work engagement. The study may potentially contribute to career and retention theory by shedding light on psychological attributes that may influence frameworks and strategies in retaining diverse age (generational) groups of employees within the South African multicultural work environment.
The next section of the article will focus on the research design, which comprises the research approach and method, followed by the presentation of the results and a discussion of the findings. The article concludes with a brief summary of the key conclusions, implications for practice and recommendations for potential future research.

\section{Research design Research approach}

A cross-sectional quantitative research approach was followed in order to achieve the research objective.

\section{Research method}

\section{Participants}

A stratified random sample of $248(N=248)$ employed adults participated in the study. The participants were employed within a media organisation situated in Gauteng. They were mostly employed on skilled level (75\%) and comprised predominantly $54 \%$ black people and $63.3 \%$ females in their early career stage $(80 \%=<45$ years $), 63.3 \%$. The representations from the different generational cohorts were Gen Y (18-40 years) 63.3\%, Gen X (40-49 years) $17.7 \%$ and Baby Boomers (50 years and older) 19.0\%.

\section{Measuring instruments}

The Psychological Career Resources Inventory: The Psychological Career Resources Inventory (PCRI) developed by Coetzee (2008) is a self-rated multifactorial measurement tool. The PCRI contains 64 items that include five subscales: career preference (17 items), career values (8 items), career enablers (8 items), career drivers (8 items) and career harmonisers (21 items). A six-point Likert-type scale was used for subject responses to each of the items. An exploratory factor analysis provided evidence of construct validity as indicated by the five-factor model, which supports the underlying dimensions of employability described by Coetzee (2008). In terms of reliability (internal consistency), Cronbach's $a$ coefficients for each subscale range from 0.79 (moderate) to 0.91 (high). In terms of the present study, the overall PCRI scale obtained a reliability coefficient of 0.95 . The internal consistency reliability coefficients for the five subscales ranged between 0.79 (career values) and 0.91 (career harmonisers).

The Career Adapt-Abilities Scale: The Career AdaptAbilities Scale (CAAS) developed by Savickas and Porfeli (2012) is a self-rated multifactorial measurement tool. The CAAS contains 24 items that include four subscales: concern (six items), control (six items), curiosity (six items) and confidence (six items). A five-point Likert-type scale was used for subject responses to each of the items. An exploratory factor analysis provided evidence of construct validity as indicated by the four-factor model, which supports the underlying dimensions of employability described by Savickas and Porfeli (2012). In terms of reliability (internal consistency), Cronbach's a coefficients 
for each subscale range from 0.83 (moderate) to 0.90 (high). In terms of the present study, the overall CAAS scale obtained a reliability coefficient of 0.94 . The internal consistency reliability coefficients for the five subscales ranged between 0.83 (control) and 0.90 (confidence).

The Utrecht Work Engagement Scale: The Utrecht Work Engagement Scale (UWES) developed by Schaufeli and Bakker (2004) is a self-rated multifactorial measurement tool. The UWES contains 21 items that include three subscales: vigour (eight items), dedication (five items) and absorption (eight items). A seven-point Likert-type scale was used for subject responses to each of the items. An exploratory factor analysis provided evidence of construct validity as indicated by the three-factor model, which supports the underlying dimensions of employability described by Schaufeli and Bakker (2004). In terms of reliability (internal consistency), Cronbach's a coefficients for each subscale range from 0.88 to 0.90 (high). In terms of the present study, the overall UWES scale obtained a reliability coefficient of 0.96 . The internal consistency reliability coefficients for the five subscales ranged between 0.88 (dedication) and 0.90 (absorption).

A biographical questionnaire was used to determine the generational cohorts (age) of the participants.

\section{Research procedure}

Nine hundred questionnaires were distributed, with a total of 248 usable questionnaires returned $(N=248)$, yielding a response rate of $28 \%$. The participants were invited to voluntarily participate in the study. The questionnaires were electronically distributed via an e-mail link. Each questionnaire included a cover letter inviting respondents to participate voluntarily in the study and assuring them that their individual responses would remain anonymous and confidential. The cover letter also stated that completing the questionnaires and returning them constituted agreement to use the results for research purposes only.

\section{Statistical analysis}

Preliminary statistical analyses assessed for common method variance and the construct validity of the three measuring instruments. Descriptive statistics (means, standard deviations and Cronbach's $a$ coefficients), stepwise regression analysis and an analysis of variance (ANOVA) test with pairwise comparison were conducted to achieve the objectives of the study. In order to counter the probability of a type I error, it was decided to set the significance value for interpreting the results at a $95 \%$ confidence level $(p \leq 0.05)$.

\section{Ethical considerations}

Ethical clearance was obtained from the University of South Africa and permission to conduct the study was obtained from the organisation.

\section{Results \\ Preliminary analysis: Common method variance and construct validity}

Because of the three self-rating measures used and the crosssectional research design of this study, the preliminary data analysis involved testing for common method variance and construct validity of each measuring scale. This procedure entailed conducting a Harmann's one-factor solution and confirmatory factor analysis (CFA) by using the CALIS procedure in SAS (2013). The one-factor solution showed that the single factor that emerged for the PCRI accounted for only $16.71 \%$ of the covariance among the PCRI variables. The 15 PCRI variables were then loaded onto one factor to examine the fit of the CFA model. The PCRI single-factor model did not fit the data adequately (chi-square or $d f$ ratio $=$ 3.68; $p<0.0001$; RMSEA $=0.11$; SRMR $=0.11$; CFI $=0.42$; AIC $=7446.88)$. The PCRI single-factor model fit indices were compared with the fit indices of a 15-factor solution measurement model for the PCRI (the 15 factors loading onto their respective meta-dimension and each of the five meta-dimensions loading on an overall latent variable: psychological career resources). The fit indices of the 15-factor measurement showed a more adequate model fit: (chi-square or $d f$ ratio $=2.23 ; p<0.0001 ;$ RMSEA $=0.06 ;$ SRMR $=0.09$; $\mathrm{CFI}=0.94 ; \mathrm{AIC}=4613.07)$. A marginal value of RMSEA and SRMR for model acceptance is 0.10 and a value of 0.08 and lower is considered a good fit (Hamtiaux, Houssemand \& Vrignaud, 2013; Park, Nam \& Cha, 2012). The indices obtained for the 15-factor PCRI model indicate adequate fit of the data, implying acceptable construct validity of the scale.

The one-factor solution for the CAAS showed that the construct accounted for only $10.24 \%$ of the covariance among the CAAS variables. When loading the four CAAS variables onto a single construct in the CFA model, the fit indices showed that the single factor did not fit the model well (chisquare or $d f$ ratio $=4.27 ; p<0.0001 ;$ RMSEA $=0.12 ;$ SRMR = 0.09; $\mathrm{CFI}=0.74 ; \mathrm{AIC}=1170.86)$. The CAAS single-factor model fit indices were compared with the fit indices of a four-factor solution measurement model for the CAAS (the four factors loading onto an overall latent variable: career adaptability). The fit indices of the four-factor measurement showed a more adequate model fit: (chi-square or $d f$ ratio $=$ 2.36; $p<0.0001$; RMSEA $=0.08$; SRMR $=0.07$; CFI $=0.90$; AIC $=687.51$ ). The indices obtained for the CAAS four-factor model indicate that the model represents the data adequately, implying acceptable construct validity of the scale.

The one-factor solution for the UWES showed that the construct accounted for only $11.65 \%$ of the covariance among the UWES variables. When loading the three UWES variables onto a single construct in the CFA model, the fit indices showed that the single factor did not fit the model well (chisquare or $d f$ ratio $=4.19 ; p<0.0001 ;$ RMSEA $=0.12 ;$ SRMR $=$ 0.06; $\mathrm{CFI}=0.84 ; \mathrm{AIC}=876.32$ ). The UWES single-factor model fit indices were compared with the fit indices of a three-factor solution measurement model for the UWES (the three factors loading onto an overall latent variable: work engagement). 
The fit indices of the three-factor measurement showed a more adequate model fit: (chi-square or $d f$ ratio $=3.76 ; p<0.0001$; RMSEA $=0.09 ;$ SRMR $=0.05 ;$ CFI $=0.90 ;$ AIC $=790.22$ ). The indices obtained for the UWES three-factor model indicate that the model represents the data adequately, implying acceptable construct validity of the scale.

Overall, in line with the guidelines of Podsakoff, Mackenzie, Lee and Podsakoff (2003), the one-factor results for the PCRI, CAAS and UWES suggested that common method bias did not pose a threat to the research findings.

\section{Descriptive statistics}

The reliability coefficients reported in Table 1 show acceptable internal consistency reliability of the three scales and the subscales. The overall reliability coefficient of the PCRI was very high $(\alpha=0.95)$ as well as the reliability coefficient for the CAAS $(\alpha=0.94)$ and the UWES $(\alpha=0.96)$. These coefficients indicated strong overall internal consistency for the three scales.

Table 1 shows that all the PCRI variables were positively and significantly associated with all the CAAS variables (range: $r \geq 0.30$ to $r \leq 0.72 ; p \leq 0.001$; moderate to large practical effect). Table 1 further shows that the overall PCRI scale significantly and positively correlated with the overall UWES scale ( $r=0.22 ; p \leq 0.001$; small practical effect). With the exception of the career preferences and career values variables, all the other PCRI variables correlated significantly and positively with the engagement variables (range: $r \geq$ 0.15 to $r \leq 0.38 ; p \leq 0.05$; small to moderate practical effect).

The overall CAAS variable positively and significantly correlated with the overall UWES variables $(r=0.33$; $p \leq 0.001$; moderate practical effect). Furthermore, positive and significant correlations were observed between all four career adaptability variables and UWES variables (range: $r \geq 0.22$ and $r \leq 0.39 ; p \leq 0.001$; small to moderate practical effect). Overall, the correlation range was below the threshold of $<0.90$ for multicollinearity concerns.

Age (generational cohort) showed a significant and positive correlation with the overall UWES $(r=0.34 ; p \leq 0.001$; moderate practical effect) and all the UWES variables of vigour, dedication and absorption (range: $r \geq 0.31$ and $r \leq 0.33 ; p \leq 0.001$; moderate practical effect). Age significantly and negatively correlated with the overall PCRI ( $r=-0.14 ; p=0.02$; small practical effect) and with the career preferences $(r=-0.27 ; p \leq 0.001$; small practical effect), career values $(r=-0.22 ; p \leq 0.001$; small practical effect $)$ and career drivers ( $r=-0.13 ; p \leq 0.05$; small practical effect). No correlations were observed between the generational cohorts (age) and the CAAS variables.

\section{Stepwise regression}

A stepwise regression analysis was conducted using generational cohort or age, PCRI variables (career

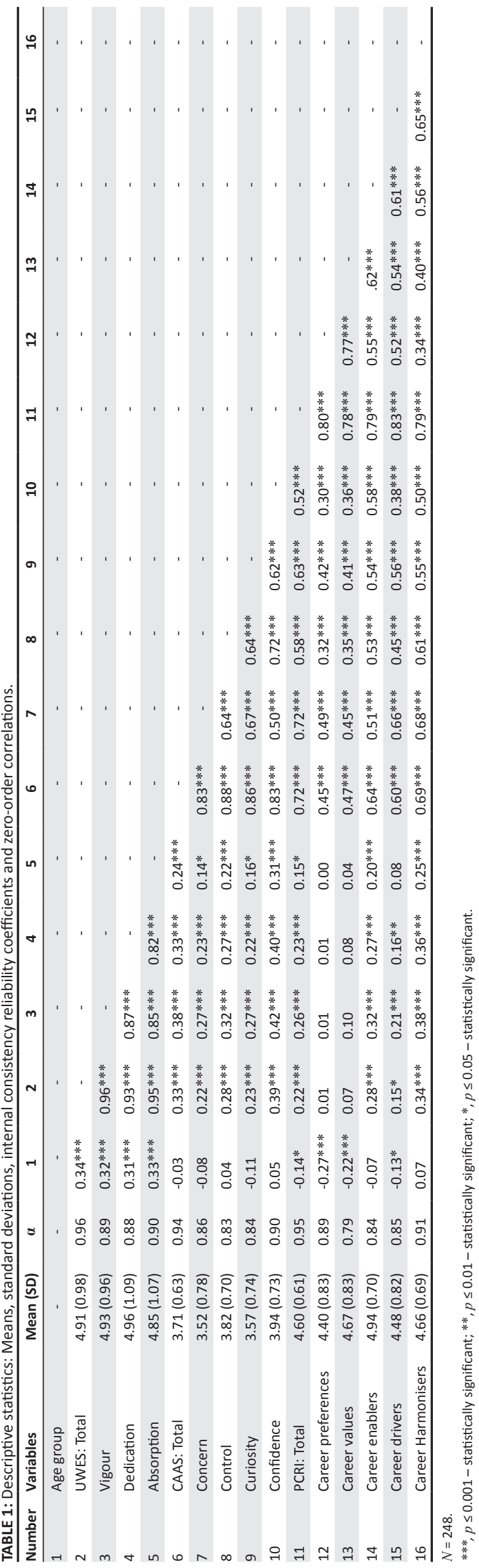


preferences, career values, career enablers, career drivers and career harmonisers) and CAAS variables (career concern, career control, career curiosity and career confidence) as the independent variables, and UWES (overall work engagement) as the dependent variable. Stepwise regression is a statistical technique that includes regression models in which the choice of predictive variables is carried out by an automatic procedure. The backward elimination procedure was applied which involves starting with all the variables and testing them one by one for statistical significance, deleting any that were not significant. Table 2 summarises the results.

The results showed that the regression model was significant $\left(F=29.93 ; p=0.000 ; R^{2}=0.27 ; \Delta R^{2}=0.02 ; \Delta F=\right.$ 5.63; $\Delta F p=0.02)$. The adjusted $R^{2}$ value of 0.27 indicated that the model predicted approximately $27 \%$ (large practical effect) of the variance in the dependent variable (work engagement). Table 2 shows that only confidence; generational cohort (age) and career harmonisers acted as significant predictors of work engagement. Generational cohort (age) contributed the most towards explaining the variance in work engagement $(\beta=0.32 ; p \leq 0.000)$, followed by career confidence $(\beta=0.29 ; p \leq 0.000)$ and the career harmonisers $(\beta=0.15 ; p \leq 0.000)$. The collinearity statistics indicated that the tolerance values were all close to 1 and the variance inflation factor (VIF) is less than 2.5 (implying little or no multicollinearity concerns).

TABLE 2: Results of the stepwise regression analysis.

\begin{tabular}{lcc}
\hline Predictor variables & \multicolumn{2}{c}{ Work engagement } \\
\cline { 2 - 3 } & 0.29 & \multicolumn{1}{c}{$\boldsymbol{t}$} \\
\hline Confidence & 0.32 & $4.53^{* * *}$ \\
Age groups & 0.15 & $5.68^{* * *}$ \\
Career harmonisers & & $2.37^{*}$ \\
Model & \\
$F p$ & $29.93^{* * *}$ & - \\
$\Delta F p$ & $5.63^{*}$ & - \\
Adjusted $R^{2}$ & 0.27 & - \\
$\Delta R^{2}$ & 0.02 & - \\
\hline$N=248$. & & \\
$* * *, p \leq .001-$ statistically significant; $* *, p \leq .01-$ statistically significant; $*, p \leq .05-$ \\
statistically significant. The final step is reported in the table. Standardised beta coefficients \\
are reported.
\end{tabular}

\section{Test for significant mean differences}

The tests for normality indicated that the data were normally distributed, a non-parametric statistical technique, namely a one-way ANOVA with pairwise comparison was applied to test for significant mean differences between the generational cohort groups.

For the purposes of statistical analysis and reporting, Baby Boomers were classified as participants 50 years and older, Generation X employees were classified as participants between the ages of 40 and 49 and Generation Y was classified as participants between the ages of 18 and 40 years.

Table 3 shows that the generational (age) cohorts differed significantly regarding the scores obtained on overall psychological career resources $(F=2.58 ; p<0.01)$, career preferences $(F=9.68 ; p<0.01)$, career values $(F=6.36$; $p<0.01)$, career drivers $(F=2.11 ; p<0.01)$, career curiosity $(F=3.49 ; p=0.03)$ and overall work engagement $(F=16.23$; $p<0.01)$.

In order to detect the source of significant differences, the Fisher's least significant difference (LSD) test was used to allow for pairwise comparisons between the generational (age) groups and the overall psychological career resources, career adaptability and work engagement variables.

\section{Psychological career resources}

Tables 3 and 4 show that the Generation Y cohort (18-40 years) scored slightly higher than the Baby Boomers (50 years and older) on the overall PCRI ( $M=4.66$ vs. $M=4.44$; $p \leq 0.001 ; d=0.37$; small practical effect). Similarly, the younger generation cohort (18-40 years) scored significantly higher than the Generation X (40-49 years) cohort on the overall PCRI $(M=4.66$ vs. $M=4.55 ; p \leq 0.001 ; d=0.37$; small practical effect). The Generation $Y$ cohort (18-40 years) scored significantly higher than the Baby Boomers (50 years and older) on the career preferences ( $M=4.56$ vs. $M=4.01$; $p \leq 0.001 ; d=0.75$; moderate practical effect). Similarly, the younger generation cohort (18-40 years) scored significantly higher than the Generation X (40-49 years) cohort on the

TABLE 3: Pairwise comparison of mean differences - ANOVA results: generational cohort (age)

\begin{tabular}{|c|c|c|c|c|c|}
\hline \multirow[t]{2}{*}{ Variables } & \multirow[t]{2}{*}{ ANOVA $(F p)$} & \multirow[t]{2}{*}{$t$} & \multicolumn{3}{|c|}{ Pairwise comparison: Significant mean differences } \\
\hline & & & Baby Boomers - Gen X & Baby Boomers - Gen Y & Gen $X$ - Gen $Y$ \\
\hline Overall work engagement & $16.23 * * *$ & $1.97^{*}$ & 0.29 & $0.81 * * *$ & $0.52 * * *$ \\
\hline Overall psychological career resources & 2.58 & $1.97 *$ & -0.11 & $-0.22 * * *$ & -0.11 \\
\hline Career preferences & $9.68 * * *$ & $1.97^{*}$ & -0.23 & $-0.55 * * *$ & $-0.32 * * *$ \\
\hline Career values & $6.36 * * *$ & $1.97 *$ & -0.19 & $-0.45 * * *$ & -0.26 \\
\hline Career drivers & 2.11 & $1.97^{*}$ & -0.13 & $-0.27 * * *$ & -0.14 \\
\hline Career enablers & 0.72 & $1.97 *$ & -0.10 & -0.14 & -0.04 \\
\hline Career harmonisers & 0.60 & $1.97 *$ & 0.01 & 0.10 & 0.10 \\
\hline Overall career adaptability & 0.63 & $1.97 *$ & -0.15 & -0.08 & 0.07 \\
\hline Concern & 0.84 & $1.97^{*}$ & -0.12 & -0.17 & -0.05 \\
\hline Curiosity & $3.49 *$ & $1.97^{*}$ & $-0.38 * * *$ & $-0.27 * * *$ & 0.11 \\
\hline Control & 0.66 & $1.97^{*}$ & -0.10 & 0.04 & 0.14 \\
\hline Confidence & 0.29 & $1.97 *$ & 0.01 & 0.08 & 0.07 \\
\hline
\end{tabular}

$N=248$.

***, $p \leq 0.001 ; * *, p \leq 0.01 ; *, p \leq 0.05$ 
TABLE 4: Means and standard deviations of significant pairwise comparisons.

\begin{tabular}{|c|c|c|c|c|c|c|}
\hline \multirow[t]{2}{*}{ Variables } & \multicolumn{2}{|c|}{ Generation $Y(18-40$ years) } & \multicolumn{2}{|c|}{ Generation X (40-49 years) } & \multicolumn{2}{|c|}{ Baby Boomers (50+ years) } \\
\hline & M & SD & M & SD & M & SD \\
\hline Overall psychological career resources & 4.66 & 0.58 & 4.55 & 0.66 & 4.44 & 0.62 \\
\hline Career preferences & 4.56 & 0.82 & 4.24 & 0.90 & 4.01 & 0.63 \\
\hline Career values & 4.80 & 0.77 & 4.54 & 0.96 & 4.34 & 0.79 \\
\hline Career drivers & 4.55 & 0.79 & 4.42 & 0.90 & 4.29 & 0.79 \\
\hline Curiosity & 3.61 & 0.74 & 3.71 & 0.75 & 3.33 & 0.68 \\
\hline Overall work engagement & 4.66 & 1.05 & 5.19 & 0.72 & 5.47 & 0.68 \\
\hline
\end{tabular}

career preferences $(M=4.56$ vs. $M=4.24 ; p \leq 0.001 ; d=0.75$; moderate practical effect). The Generation Y cohort (18-40 years) scored significantly higher than the Baby Boomers (50 years and older) on the career values $(M=4.80$ vs. $M=4.34 ; p \leq 0.001 ; d=0.60$; moderate practical effect). Similarly, the younger generation cohort (18-40 years) scored significantly higher than the Generation X (40-49 years) cohort on the career preferences ( $M=4.80$ vs. $M=4.54 ; p \leq 0.001 ; d=0.75 ;$ moderate practical effect). The Generation Y cohort (18-40 years) scored significantly higher than the Baby Boomers (50 years and older) on the career drivers $(M=4.55$ vs. $M=4.29 ; p \leq 0.001 ; d=0.33$; small practical effect). Similarly, the younger generation cohort (18-40 years) scored significantly higher than the Generation X (40-49 years) cohort on the career preferences $(M=4.55$ vs. $M=4.42 ; p \leq 0.001 ; d=0.33$; small practical effect).

\section{Career adaptability}

Tables 3 and 4 show that the Generation X cohort (40-49 years) scored significantly higher than the Baby Boomers (50 years and older) on the curiosity $(M=3.71$ vs. $M=3.33$; $p \leq 0.001 ; d=0.53$; moderate practical effect). Similarly, the older generation cohort (40-49 years) scored significantly higher than the Generation Y (18-40 years) cohort on the curiosity $(M=3.71$ vs. $M=3.61 ; p \leq 0.001 ; d=0.53$; moderate practical effect).

\section{Work engagement}

Tables 3 and 4 show that the Baby Boomers (50 years and older) scored significantly higher than the Generation $Y$ cohort (18-40 years) on the overall UWES ( $M=5.47$ vs. $M=$ 4.66; $p \leq 0.001 ; d=0.96$; large practical effect). Similarly, the Baby Boomers (50 years and older) scored significantly higher than the Generation X (40-49 years) cohort on the overall UWES ( $M=5.47$ vs. $M=5.19 ; p \leq 0.001 ; d=0.96$; large practical effect).

\section{Discussion}

The study explored individuals' age, psychological career resources and career adaptability in relation to their work engagement and how these manifest in the three generational cohorts: Generation Y (18-40 years), Generation X (40-49 years) and Baby Boomers (50+ years).

Overall, the findings of the present study suggest that work engagement is likely to be influenced by an individual's generational cohort (age), their confidence in engaging in career self-management behaviour (Savickas \& Porfeli, 2012) and to a lesser extent their psychological career capacities (Coetzee, 2014) comprising their self-esteem, behavioural adaptability, emotional literacy and social connectivity (career harmonisers). The findings corroborate previous research that showed that individuals who feel more efficacious (confident) in their capacity to solve problems and surmount challenges and obstacles in the pursuit of constructing their careers will most likely feel more engaged in their work (Hartung, 2013; Potgieter, 2012). Coetzee (2014) suggests that career harmonisers such as behavioural adaptability are associated with an individual's selfperceived success in important areas such as self-esteem and positive social interactions, self-sufficiency, personal growth, drive, environmental mastery and optimism. It appears from this study's findings that intrinsic motivational behavioural orientations underlying the career harmonisers act as important personal resources in activating and enhancing the work engagement of the participants. The findings are also in agreement with previous South African research studies that suggest that building a well-developed psychological career resources profile and especially capitalising on one's career harmonisers positively contribute to subjective work experiences such as work engagement and retention-related dispositions (career foci, vigour and absorption) (Tladinyane, 2013; Venter, Coetzee \& Basson, 2013). The proactive career behaviour associated with individuals' psycho-social career meta-capacities may translate into greater discretionary effort and energy invested in their work (Bakker \& Demerouti, 2008; Rossier et al., 2012).

The Generation Y individuals had higher levels of psychological career resources (career preferences, career values and career drivers), while the Generation $X$ individuals had higher career curiosity than the other two generational cohorts. The Baby Boomers showed higher levels of work engagement than the other two generational cohorts. Generational cohort research highlights that Baby Boomers value achievement, hierarchy and advancement fulfilment (Cennamo \& Gardner, 2007; Kupperschmidt, 2000; Smola \& Sutton, 2002; Zemke, Raines \& Filipczak, 2000) which may explain their higher levels of engagement. However, research on age and work engagement has been highly inconsistent. The findings support some research that has found Baby Boomers to be the most engaged generational cohort (Park \& Gursoy, 2012; Schaufeli et al., 2006, 2009). These findings highlight that Baby Boomers should not be assumed to be the 'dead wood' of the organisation, as they were found to possess significantly high levels of work engagement. 
The higher levels of psychological career resources (career preferences, career values and career drivers) observed for the youngest generational cohort (Generation Y: 18-40 years) could be attributed to them being in the early stages of their careers. The findings suggest that they have a higher need for clarifying their career motives, interests and values and are seemingly therefore more purposeful (driven) in clarifying the meaning of work for them, having clear career direction and exploring various avenues in which their career paths may unfold (Coetzee, 2014). The findings corroborate research that has reported that younger individuals' tend generally to be more adaptable to their career context because of their higher acceptance of change and job insecurity and higher inclination towards career exploration (Gursoy, Chi \& Karadag, 2013; Ismail et al., 2016; Potgieter, 2012; Zemke et al., 2000).

The higher level of career curiosity of the Generation $X$ participants (40-49 years) could be attributed to them being in the establishment phase of their careers, which could explain the stronger need for having clarity about their career path in the organisation (Savickas \& Porfeli, 2012). This finding supports previous studies that found that respondents between the ages of 41 and 45 years were more curious about looking ahead and exploring future possibilities (Potgieter, 2012; Savickas \& Porfeli, 2012).

\section{Study limitations and future suggestions}

The present study was limited to a stratified random sample of predominantly early career stage African female employees in a South African media company. The findings cannot therefore be generalised to other age contexts. Furthermore, given the cross-sectional nature of the research design, this study can yield no statements about causation. Associations between the variables have therefore been interpreted rather than established. Longitudinal studies should be employed to establish the causal relationships among the variables. Further studies are needed with broader samples across various occupational, age and gender groups, cultural groups and economic sectors to replicate and extend the findings.

\section{Conclusion}

\section{Implications for practice}

The findings may potentially inform interventions within organisations to enhance the work engagement of the different generational cohort groups for retention purposes. The results of the study emphasise the importance of considering the influence of generational cohorts (age), psychological career resources and career adaptability on work engagement in order to assist organisations with the retention of valuable staff. The significant lower levels of engagement of the younger generations should be considered in the light of their higher concerns about their career development. Formal career discussions and clear career paths for the younger generations who are still in the early stages of their career may potentially influence their work engagement and retention. It is concluded that the findings contribute new knowledge to the field of career psychology and the media sector's career development practices. Understanding how these three constructs are related can help initiate career paths that support employee development, career mobility, career management and retention practices.

\section{Acknowledgements}

This research received no specific grant from any funding agency in the public, commercial, or non-profit sectors.

\section{Competing interests}

The authors declare that they have no financial or personal relationships that may have inappropriately influenced them in writing this article.

\section{Authors' contributions}

N.F. and M.C. were the project leaders and wrote the manuscript. C.S. was responsible for the data collection and analysis of the data.

\section{References}

Bakker, A.B., \& Demerouti, E. (2008). Towards a model of work engagement. Career Development International, 13(3), 209-223. https://doi.org/10.1108/1362043 0810870476

Bezuidenhout, M. (2011). The development and evaluation of a measure of graduate employability in the context of the new world of work. Unpublished master's dissertation. Pretoria, South Africa: University of Pretoria.

Boone-James, J., Mckechnie, S., \& Swanberg, J. (2011). Predicting employee engagement in an age-diverse retail workforce. Journal of Organizationa Behaviour, 32, 173-196. https://doi.org/10.1002/job.681

Breevaart, K., Bakker, A.B., Demerouti, E., \& Hetland, J. (2012). The measurement of state work engagement: A multilevel factor analytic study. European Journal of Psychological Assessment, 28, 305-312. https://doi.org/10.1027/1015-5759/ a000111

Brown, A., Bimrose, J., Barnes, S.A., \& Hughes, D. (2012). The role of career adaptabilities for mid-career changers. Journal of Vocational Behavior, 80, 754-761. https://doi.org/10.1016/j.jvb.2012.01.003

Cates, S.V. (2010). Generational management in corporate America: The differences and challenges in management of four generations of working adults. Chinese Business Review, 9(8), 46-54.

Cennamo, L., \& Gardner, D. (2007). Generational differences in work values, outcomes and person- organisation values fit. Journal of Managerial Psychology, 23(8), 891-906. https://doi.org/10.1108/02683940810904385

Chabault, D., Hulin, A., \& Soparnot, R. (2012). Talent management in clusters. Organizational Dynamics, 41(4), 327-335. https://doi.org/10.1016/j.orgdyn.2012. 08.008

Coetzee, M. (2008). Psychological career resources and subjective work experience of working adults: A South African survey. South African Journal of Industrial Psychology, 34(2), 32-41. https://doi.org/10.4102/sajip.v34i2.491

Coetzee, M. (2014). A psychological career resources framework for contemporary career development. In M. Coetzee (Ed.), Psycho-social career meta-capacities: Dynamics of contemporary career development (pp. 87-122). Dordrecht: Springer International.

Coetzee, M., \& Bergh, Z. (2009). Psychological career resources and subjective work experiences of working adults: An exploratory study. Southern African Business Review, 13(2), 1-31.

Coetzee, M., \& Esterhuizhen, K. (2010). Psychological career resources as predictors of African graduates' coping resources: An exploratory study. South African Journal of Industrial Psychology, 36(1), Art. \#833, 1-13. https://doi.org/10.4102/sajip. v36i1.868

Coetzee, M., \& Roythorne-Jacobs, H. (2012). Career counselling and guidance in the workplace (2nd ed.). Cape Town: Juta.

Coetzer, C.F., \& Rothmann, S. (2007). Job demands, job resources and work engagement of employees in a manufacturing organisation. Southern African
Business Review, 11(1), 17-32.

Converse, P.D., Pathak, J., DePaul-Haddock, A.M., Gotlib, T., \& Merbedone, M. (2012). Controlling your environment and yourself: Implications for career success. Journal of Vocational Behavior, 80, 148-159. https://doi.org/10.1016/j. jvb.2011.07.003 
Del Corso, J., \& Rehfuss, M. (2011). The role of narrative in career construction theory. Journal of Vocational Behavior, 79, 334-339. https://doi.org/10.1016/j. jvb.2011.04.003

Drake, T.J. (2012). Assessing employee engagement: A comparison of the job engagement scale and the Utrecht Work Engagement Scale. Retrieved June 16 2015, from http://digitool.library.colostate.edu/exlibris/dtl/d3 1/apache media/ L2V4bGlicmlzL2RObC9kM18xL2FWYWNoZV9tZWRpYS8xNzA3MzM=.pdf

Ebberwein, C.A., Krieshok, T.S., Ulven, J.C., \& Prosser, E.C. (2004). Voices in transition: Lessons on career adaptability. The Career Development Quarterly, 52(4), 292-308. https://doi.org/10.1002/j.2161-0045.2004.tb00947.x

Ferreira, N. (2012). Constructing a psychological career profile for staff retention. Doctoral thesis. Pretoria, South Africa: University of South Africa.

Ferreira, N., Basson, J., \& Coetzee, M. (2010). Psychological career resources in relation to commitment: An exploratory study. South African Journal of Human Resource Management, 8(1), 1-10. https://doi.org/10.4102/sajhrm.v8i1.284

Ferreira, N., \& Coetzee, M. (2010). The influence of job embeddedness on black employees' organisational commitment. Southern African Business Review, 17(3) 239-255.

Festing, M., \& Schafer, L. (2014). Generational challenges to talent management: A framework for talent retention based on the psychological-contract perspective. Journal of World Business, 49, 262-271. https://doi.org/10.1016/j.jwb.2013. 11.010

Fugate, M., Kinicki, A., \& Ashforth, B. (2004). Employability: A psycho-social construct, its dimensions and applications. Journal of Vocational Behaviour, 65, 14-38. https://doi.org/10.1016/j.jvb.2003.10.005

Guan, Y., Guo, Y., Bond, M.H., Cai, Z., Zhou, X., Xu, J., et al. (2014). New job market entrants' future work self, career adaptability and job search outcomes: Examining entrants future work self, career adaptability and job search outcomes: Examining
mediating and moderating variables. Journal of Vocational Behavior, 85, 136-145. https://doi.org/10.1016/j.jvb.2014.05.003

Guest, D.E., Isaksson, K., \& De Witte, H. (2010). Employment contracts, psychological contracts, and worker well-being: An international study. Oxford, UK: Oxford contracts, and
University Press.

Gunz, H. P., \& Heslin, P. A. (2005). Reconceptualizing career success. Journal of Organizational Behavior, 26, 105-111. https://doi.org/10.1002/job.300

Gursoy, D., Chi, C.G., \& Karadag, E., (2013). Generational differences in work values and attitudes among frontline and service contact employees. International Journal of Hospitality Management, 31, 40-48. https://doi.org/10.1016/j.ijhm. 2012.04.002

Hall, D.T., \& Chandler, D.E. (2005). Psychological success: When the career is a calling Journal of Organisational Behaviour, 26(2), 155-176. https://doi.org/10.1002/ job.301

Hallberg, U., \& Schaufeli, W.B. (2006). 'Same same' but different? Can work engagement be discriminated from job involvement and organizational commitment? European Psychologist, 11, 119-127. https://doi.org/10.1027/1016 9040.11.2.119

Hamtiaux, A., Houssemand, C., \& Vrignaud, P. (2013). Individuals and career adaptability: Comparing models and measures. Journal of Vocational Behaviour, 83(2), 130-141. https://doi.org/10.1016/j.jvb.2013.03.006

Hartung, P.J. (2013). The life-span, life-space theory of careers. In S.D. Brown \& R.W. Lent (Eds.), Career development and counseling: Putting theory and research to work (2nd ed., pp. 83-113). Hoboken, NJ: Wiley.

Hobfoll, S.E., Johnson, R.J., Ennis, N., \& Jackson, A.P. (2003). Resource loss, resource gain, and emotional outcomes among inner city women. Journal of Personality and Social Psychology, 84, 632-643. https://doi.org/10.1037/0022-3514.84.3.632

Hoole, B., \& Bonnema, J. (2015). Work engagement and meaningful work across generational cohots. South African Journal of Human Resource Management, generational cohots. South African Journal of Human Resource M

International Labour Office. (2014). Issues paper for the Global Dialogue Forum on employment relationships in the media and culture sector. Geneva: International Labour Office.

Ismail, S., Ferreira, N., \& Coetzee, M. (2016). Young emerging adults' graduateness and career adaptability: Exploring the moderating role of self-esteem. Journal of Psychology in Afriica, 26(1), 1-10. https://doi/10.1080/14330237.2016.1148417

Johnston, C.S., Luciano, E.C., Maggiori, C., Ruch, W., \& Rossier, J. (2013). Validation of the German version of the Career Adapt-Abilities Scale and its relation to orientations to happiness and work stress. Journal of Vocational Behavior, 83(3), 295-304. https://doi.org/10.1016/j.jvb.2013.06.002

Kahn, W., \& Heapy, E.D. (2014). Relational contexts of personal engagement at work In C. Truss, R. Delbridge, E. Soane, K. Alfes \& A. Shantz (eds.) Employee engagement in theory and practice (pp. 163-179). Abingdon: Routledge.

Kapoor, C., \& Solomon, N. (2011). Understanding and managing generational differences in the workplace. Worldwide Hospitality and Tourism Themes, 3(4), 308-318. https://doi.org/10.1108/17554211111162435

Klehe, U.C., Zikic, J., Van Vianen, A.E., Koen, J., \& Buyken, M. (2012). Coping proactively with economic stress: Career adaptability in the face of job insecurity, job loss, unemployment and underemployment. Research in Occupational Stress and Well-Being, 10, 131-176. https://doi.org/10.1108/S1479-3555(2012)000 0010008

Kupperschmidt, B.R. (2000). Multigeneration employees: Strategies for effective management. Health Care Manager, 19(1), 65-76. https://doi.org/10.1097/00126 450-200019010-00011

Lent, R. (2013). Career -life preparedness: Revisiting career planning and adjustment in the new workplace. The Career Development Quarterly, 61, 1-14. https://doi. org/10.1002/j.2161-0045.2013.00031.x
Linley, P.A., Nielsen, K.M., Gillett, R., \& Biswas-Diener, R. (2010). Using signature strenghts in pursuit of goals: Effects on goal progress, need satisfaction, and wellbeing, and implications for coaching psychologists. International Coaching being, and implications for coar
Psychology Reviews, 5(1), 6-15.

Lyons, S., Duxbury, L., \& Higgins, C. (2006). Are generational differences in basic human values a generational phenomenon? Sex Roles, 53(9), 763-778.

Macey, W.H., \& Schneider, B. (2008). The meaning of employee engagement Industrial and Organizational Psychology, 1(1), 3-30. https://doi.org/10.1111/j. 1754-9434.2007.0002x

Maggiori, C., Johnston, C.S., Krings, F., Massoudi, K., \& Rossier, J. (2013). The role of career adaptability and work conditions on general and professional well-being. Journal of Vocational Behavior, 83(3), 437-449. https://doi.org/10.1016/j.jvb.2013.07.001

Maslach, C., Schaufeli, W.B., \& Leiter, M.P. (2001). Job burnout. Annual Review of Psychology, 53, 397-422. https://doi.org/10.1146/annurev.psych.52.1.397

Mendes, F., \& Stander, M.W. (2011). Positive organisation: The role of leader behaviour in work engagement and retention. South African Journal of Industrial Psychology 37(1), 29-41. https://doi.org/10.4102/sajip.v37i1.900

Miller, B., \& Nyce, S. (2014). Which workers are delaying retirement and why? Retrieved October 12, 2014 from http://www.towerswatson com/en/Insights/Newsletters/ Americas/Insider/2014/which-employees-are-delaying-retirement-and-why

Mohlala, J., Goldman, G.A., \& Goosen, X. (2012). Employee retention within the Information Technology Division of a South African Bank. SA Journal of Human Resource Management, 10(2), 1-11. https://doi.org/10.4102/sajhrm.v10i2.438

Naute, A., Van Vianen, A., Van Der Heijden, B., Van Dam, K., \& Willemsen, M. (2009) Understanding the factors that promote employability orientation: The impact of employability culture, career satisfaction, and the role breadth self-efficacy. Journal of Occupational and Organsational Psychology, 82, 223-251. https://doi. org/10.1348/096317908X320147

Nkomo, E. (2013). Motivation, work values, organisational commitment and job satisfaction: Age and generational cohort effects. Retrieved 15 March, 2014, from http://wiredspace.wits.ac.za/handle/10539/13994

Obschonka, M., Silbereisen, R.K., \& Wasilewski, J. (2012). Constellations of new demands concerning careers and jobs: Results from a two-country study on social and economic change. Journal of Vocational Behavior, 80, 211-223. https://doi. org/10.1016/j.jvb.2011.08.002

Olckers, C., \& Du Plessis, Y. (2012). The role of psychological ownership in retaining talent: A systematic literature review. SA Journal of Human Resource Management 10(2), 1-18. https://doi.org/10.4102/sajhrm.v10i2.415

Öncel, L. (2014). Career Adapt-Abilities Scale: Convergent validity of subscale scores. Journal of Vocational Behavior, 85, 13-17. https://doi.org/10.1016/j.jvb.2014.03.006

Park, J., \& Gursoy, D. (2012). Generation effects on work engagement among U.S. hotel employees. Intenational Journal of Hospitality Management, 31(4), 1195-1202. https://doi.org/10.1016/j.ijhm.2012.02.007

Park, S.Y., Nam, M., \& Cha, S. (2012). University students' behavioural intention to use mobile learning: Evaluating the technology acceptance model. British Journal of Educational Technology, 43(4), 592-605. https://doi.org/10.1111/j.1467-8535. 2011.01229.x

Podsakoff, P.M., Mackenzie, S.B., Lee, J., \& Podsakoff, N.P. (2003). Common method biases in behavioural research: A critical review of the literature and recommended remedies. Journal of Applied Psychology, 88(5), 879-903. https://doi.org/ 10.1037/0021-9010.88.5.879

Potgieter, I.L. (2012). The development of a career meta-compenetncy model for sustained employability. Unpublished doctoral thesis. University of South Africa.

Rothmann, S., \& Rothmann, S. (2010). Factors associated with employee engagement in South Africa. SA Journal of Industrial Psychology, 36(2), 27-38. https://doi. org/10.4102/sajip.v36i2.925

Rossier, J., Zecca, G., Stauffer, S.D., Maggiori, C., \& Dauwalder, J.P. (2012). Career Adapt-Abilities Scale in a French-speaking Swiss sample: Psychometric properties and relationships to personality and work engagement. Journal of Vocational Behavior, 80(3), 734-743. https://doi.org/10.1016/j.jvb.2012.01.004

Rottinghaus, P.J., Buelow, K.L., Matyja, A., \& Schneider, M.R. (2012). The career futures inventory-revised: Measuring dimensions of career adaptability. Journal of Career Assessment, 20(2), 123-139. https://doi.org/10.1177/1069072711420849

Saks, A. (2006). Antecedents and consequences of employee engagement. Journal of Managerial Psychology, 21(7), 600-619. https://doi.org/10.1108/026839406 10690169

Santilli, S., Nota, L., Ginevra, M.C., \& Soresi, S. (2014). Career adaptability, hope and life satisfaction in workers with intellectual disability. Journal of Vocational life satisfaction in workers with intellectual disability. Journal
Behavior, 85, 67-74. https://doi.org/10.1016/j.jvb.2014.02.011

Savickas, M. (1997). Career adaptability: An integrative construct for life-span, lifespace theory. Career Development Quaterly, 45(3), 247-259. https://doi. org/10.1002/j.2161-0045.1997.tb00469.x

Savickas, M.L. (2012). Life design: A paradigm for career intervention in the 21st century. Journal of Counseling and Development, 90(1), 13-19. https://doi. org/10.1111/j.1556-6676.2012.00002.x

Savickas, M.L., \& Porfeli, E.J. (2012). Career Adapt-Abilities Scale: Construction, reliability, and measurement equivalence across 13 countries. Journal of Vocational Behavior, 80, 661-673. https://doi.org/10.1016/j.jvb.2012.01.011

Schaufeli, W., \& Bakker, A.B. (2004). Utrecht Work Engagement Scale preliminary manual version 1.1. Retrieved 15 March, 2016, from http://www.schaufeli.com

Schaufeli, W., Bakker, A.B., \& Salanova, M. (2006). The measurement of work engagement with a short questionnaire: A cross-national study. Educational and Psychological Measurement, 66(4), 701-716. https://doi.org/10.1177/0013 164405282471 
Schaufeli, W., Bakker, A.B., \& Van Rhenen, W. (2009). How changes in job demands and resources predict burnout, work engagement, and sickness absenteeism.
Journal of Organizational Behavior, 30, 893-917. https://doi.org/10.1002/ job.595

Schaufeli, W.B. (2013). What is engagement? In C. Truss, K. Alfes, R. Delbridge, A. Shantz, \& E. Soane (Eds.), Employee engagement in theory and practice (pp. 15-35). London: Routledge.

Schuler, R.S., Jackson, S.E., \& Tarique, I. (2011). Global talent management and global talent challenges: Strategic opportunities for IHRM. Journal of World Business, 46(4), 506-516. https://doi.org/10.1016/j.jwb.2010.10.011

Segers, J., \& Inceoglu, I. (2012). Exploring supportive and developmental caree management through business strategies and coaching. Human Resource Management, 51, 99-120. https://doi.org/10.1002/hrm.20432

Shunmugum, C. (2016). Psycho-social career meta-capacities, work engagement and generational cohorts in a media organisation in South Africa. Unpublished masters dissertation. Pretoria: University of South Africa.

Smola, K.W., \& Sutton, C.D. (2002).Generational differences; revisiting generational work values for the new millennium. Journal of Organisational Behaviour, 23(40), 363-382. https://doi.org/10.1002/job.147

Tansley, C. (2011). What do we mean by the term 'talent' in talent management? Industrial \& Commercial Training, 43(5), 266-274. https://doi.org/10.1108/00197 851111145853
Thunnissen, M., Boselie, P., \& Fruytier, B. (2013). Talent management and the relevance of context: Towards a pluralistic approach. Human Resource Management Review, 23(4),326-336. https://doi.org/10.1016/j.hrmr.2013.05.004

Tladinyane, R.T. (2013). Psychological career resources, work engagement and organisational commitment: A psychological profile for staff retention. Unpublished doctoral thesis. Pretoria, South Africa: University of South Africa.

Tolentino, L.R., Garcia, P.R.J.M., Restubog, S.L.D., Bordia, P., \& Tang, R.L. (2013) Validation of the Career Adapt-Abilities Scale and an examination of a model of career adaptation in the Philippine context. Journal of Vocational Behavior, 83(3), 410-418. https://doi.org/10.1016/j.jvb.2013.06.013

Venter, J., Coetzee, M., \& Basson, J.S. (2013). Psychological career resources and work engagement of early career consulting staff. Journal of Psychology in Africa, 23(3), 431-438.

Venus, M. (2011). The multi-generational workplace - How employers can help silents, Boomers, Gen Xers and millennials work together (pp. 7-10). Northern Colorado Business Report, CO: Diversity Supplement.

Zacher, H. (2014). Career adaptability predicts subjective career success above and beyond personality traits and core self-evaluations. Journal of Vocational Behavior, 84, 21-30. https://doi.org/10.1016/j.jvb.2013.10.002

Zemke, R., Raines, C., \& Filipczak, B. (2000). Generations at work: Managing the clash of the veterans, boomers, xers and nexters in your workplace. New York: American Management Association. 